\title{
Comparative Performance Evaluation of a Diesel Engine Run on Diesel and Biodiesel Produced from Coconut Oil
}

\author{
*MUSA, NA; TERAN, GM; YAMAN, SA \\ Mechanical Engineering Department, Federal University of Technology, Minna, Niger State Nigeria. \\ *Corresponding Author Email: Madonick1@yahoo.com
}

\begin{abstract}
Using renewable alternative fuel such as biodiesel in the diesel engines has long been advocated for. The aim of the study was to experimentally investigate and compare the performance in terms of fuel consumption rate, brake power, mechanical efficiency of a diesel engine individually fuelled by sole coconut oil biodiesel and diesel. All the tests were conducted using a test rig at different engine loads of $0,25,50,75$ and $100 \%$. Results of the test revealed that fuel consumption rate of the engine when it was fuelled by coconut oil biodiesel were 3.651, 4.058, 4.465, 3.113 and 1.76litres/h and were $2,1.55,1.10,1.06$ and 1.02 litres/h when the engine was fuelled by sole diesel at the respective aforementioned engine loads. The brake powers of the engine when biodiesel was used were found to be lower than when diesel was used at each load The mechanical efficiencies of the engine when biodiesel was used were found to be slightly lower at each load than when diesel was used. The fuel consumption rates of the diesel engine when fuelled individually with sole biodiesel and sole diesel were found to vary with load, brake power and mechanical efficiency of the engine. Brake power was also found to vary with load when the engine was fuelled individually with sole biodiesel and sole diesel.
\end{abstract}

DOI: https://dx.doi.org/10.4314/jasem.v23i4.18

Copyright: Copyright (C) 2019 Musa et al. This is an open access article distributed under the Creative Commons Attribution License (CCL), which permits unrestricted use, distribution, and reproduction in any medium, provided the original work is properly cited.

Dates: Received: 05 February 2019; Revised: 26 March 2019; Accepted 24 April 2019

Keywords: Diesel engine, diesel, biodiesel, fuel consumption, performance

The choice of diesel engines as power sources in preference to gasoline engines is because, gasoline engines consume so much fuel with high exhaust emissions like carbon dioxide and un combusted hydrocarbon (Adaileh and AlQdah, 2012).Most countries meet their energy needs with fossil fuels such as petroleumbut as the population increases, the demand of the use of fossil fuel increases and this leads to imminent exhaustion of the fossil fuel sources (Puneet and Sharma, 2015). According to Tutunea and Dumitru (2017), the increasingly use of fossil fuels in the world by burning to produce energy or power, hampers the environment by the emissions of gases that are responsible for global warming and also affect our health. To forestall this, researchers are keenly in search of other feasible energy. Biodiesel has been seen as a dependable energy resource as a result of its renewable nature which can be used as a sole or in blends with petroleum. However, Friso (2014) reiterated that the use of sole biodiesel shows laudable environmental achievement, despite the nonfeasibility of using it as a whole at present as result of economic implications. The need to know biodiesel performance benefits is very imperative. However this need has necessitated some researchers to carry out comparative performance analysis of diesel engine fuelled with biodiesel produced from different sources and diesel by Naik and Balakrishna (2019),Jindal et al., (2010),Ashutosh et al., (2013), Nidal and Khaled (2015), Ghosh and Dutta (2012), Mamilla et al.,(2013), Hao et al.,(2016), Al-dawody and AlFarhany (2018), Kolhe et al., (2014), Dharmadhikari et al.,(2012),Kumar and Sharma (2016), Ramakrishnan et al., (2018), Hevandro et al.,(2017),Fallahipanah et al.,(2011), Ahmed et al., (2016),Maharana and Chnadra (2015), Hurdogan (2016),Harinathareddy et al.,(2013), Elango and Senthilkumar (2011), Mamilla (2013), Musa et al.,(2016a).

Performance evaluation of a diesel engine run on coconut oil based biodiesel and its blends has been carried out by Musa et al., (2016a). Nevertheless, emphases were on brake specific fuel consumption in relation to engine load and brake power, mechanical efficiency, in relation to engine load and brake power. Fuel consumption rate was deemphasized. According to Watson et al., (2008), fuel consumption is one of the common indices used to determine the efficiency and performance of a diesel engine. This study therefore focuses on fuel consumption rate and its relation to engine load, brake power and mechanical efficiency of the engine. More so, on brake power in relation to engine load using sole coconut oil biodiesel in comparison to sole diesel in fuelling diesel engine.

\section{MATERIALS AND METHODS}

Diesel fuel bought from retail market of Nigerian National Petroleum Cooperation (NNPC) and biodiesel produced from coconut oil and characterized by Musa et al., (2016b) were used for this study. The test rig shown in plate I (Musa et al., 2016a) was used to carry out test. It includes GD411 diesel Honda 9.0 an air cooled, 4-cycles, single cylinder and 9 horse 
power engine manufactured by Honda Motor Company, Japan, coupled to dynamometer, equipped with sensors, data acquisition and digital display systems as stated by Musa et al.,(2016a).

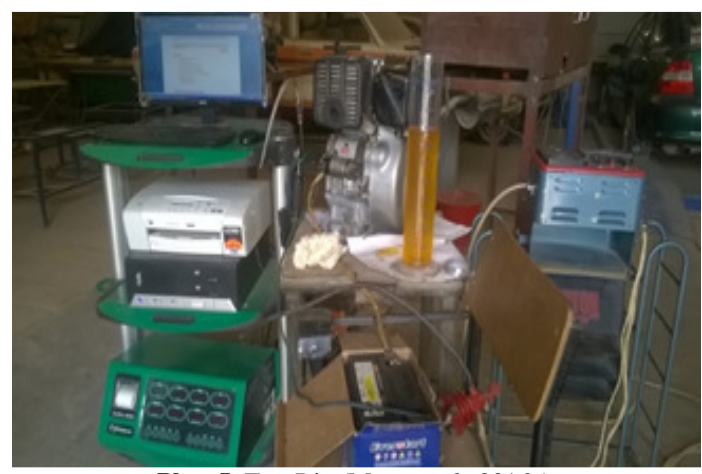

Plate I: Test Rig (Musa et al., 2016a).

Experimental procedure: The engine was run for 30 minutes (Savariraj et al., 2013) with diesel fuel at constant speed of 1000rpm which was measured by digital Tachometer. The engine load was applied by employing dynamometer that was coupled to it. The fuel consumption rate was measured using a glass burette and stopwatch. After completing the experiment with diesel, the engine was run with coconut oil biodiesel (Musa et al., 2016a). Each test was repeated five times and the average readings were used for calculation and analysis. The performance parameters determined, include fuel consumption rate, engine load, brake power and mechanical efficiency.

\section{RESULTS AND DISCUSSION}

The variation of fuel consumption rate of the engine when it was run with biodiesel and diesel with engine load is shown in figure 1.It can be seen from figure 1 that when the engine was fuelled with biodiesel and made to run, the fuel consumption rate initially increased with increase in engine load and finally decreased sharply with increase in engine load. It can also be seen from figure 1 that when the engine was fuelled with diesel and made to run, the fuel consumption rate initially decreased sharply and then steadily with increase in engine load. The fuel consumption rates of the engine when biodiesel was used are higher at each load than when diesel was used. Fuel consumption rate increase with increase in engine load could be attributed to increase in fuel conversion efficiency (Madalli, 2018).

Fuel consumption decreased with increase in engine load could be as a result of the increase percentage of required fuel for the engine operation was less than the increase percentage of brake power because of relatively less portion of the heat losses at higher loads(Che, 2018).

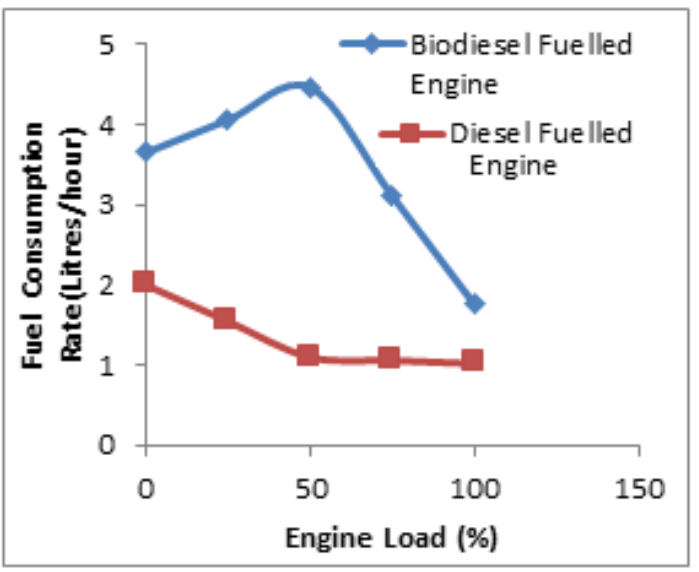

Fig 1. Variation of fuel consumption rate of the engine when it was run with biodiesel and diesel with engine load.

The variation of fuel consumption rate of the engine when it was run with biodiesel and diesel with brake power is shown in figure 2.

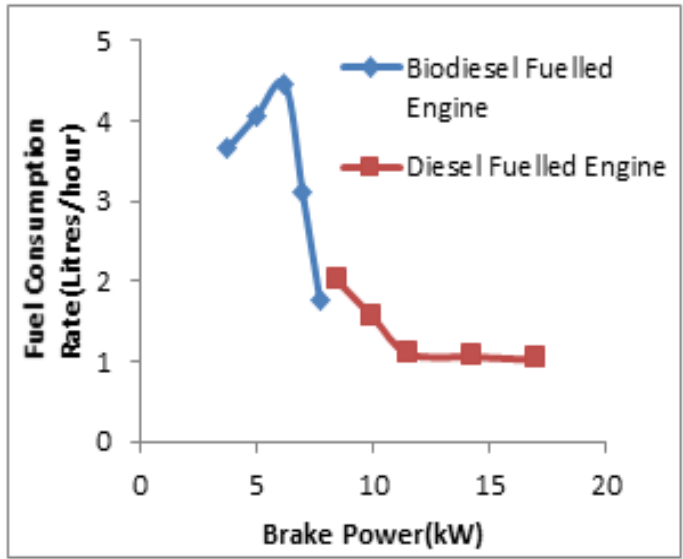

Fig 2. Variation of fuel consumption rate of the engine when it was run with biodiesel and diesel with brake power.

As can be seen from figure 2 that the fuel consumption rate of the biodiesel fuelled engine initially increased and later decreased with increase in brake power. It can also been seen from figure 2 , that fuel consumption rate decreased with increase in brake power when the engine was fuelled with diesel.

The brake powers of the engine when biodiesel was used were found to be lower than when diesel was used at each load. The variation of fuel consumption rate of the engine when it was run with biodiesel and diesel with mechanical efficiency is shown in figure 3. 
Fuel consumption rate of biodiesel fuelled engine increased steadily and decreased steadily with increase in the mechanical efficiency of the engine as evident in figure 3.

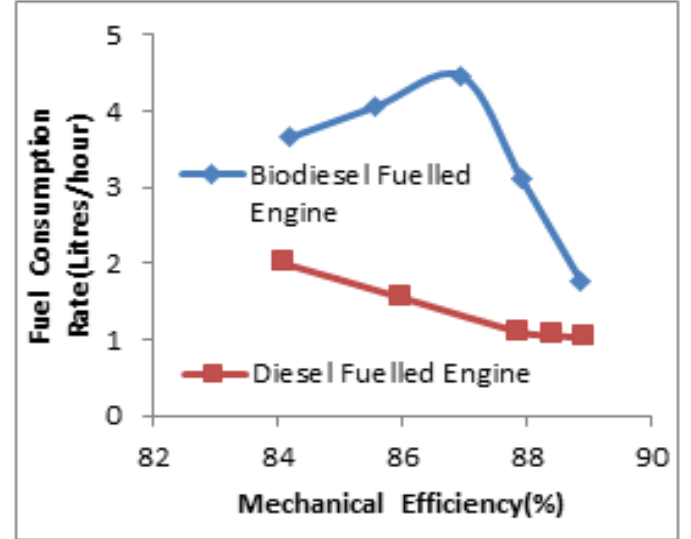

Fig 3. Variation of fuel consumption rate of the engine when it was run with biodiesel and diesel with mechanical efficiency.

Also evident in figure 3, the fuel consumption rate of the engine fuelled with diesel decreased with increase in mechanical efficiency of the engine. The mechanical efficiency of the engine when biodiesel was used was found to be slightly lower at each load than when diesel was used. The variation of brake power of the engine when it was run with biodiesel and diesel with engine load is shown in figure 4.

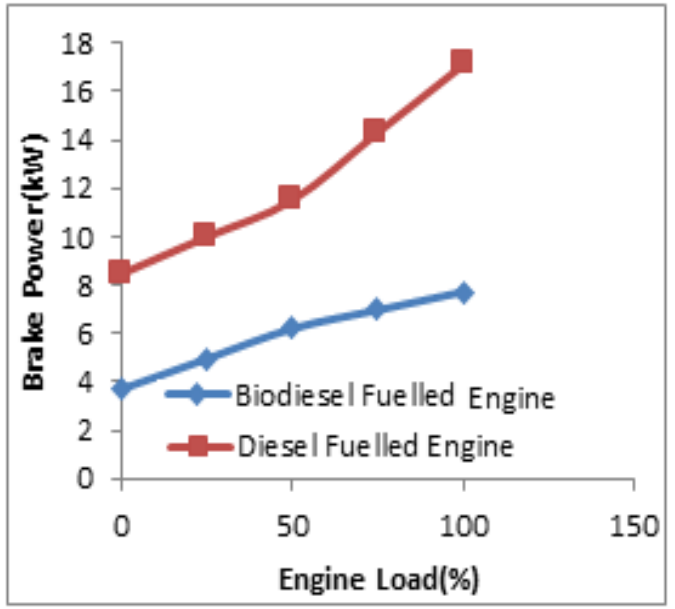

Fig 4. Variation of brake power of the engine when it was run with biodiesel and diesel with engine load.

Figure 4 revealed that the brake power of the engine fuelled with biodiesel increases with increase in engine load. Moreso, revealed that the engine fuelled with diesel exhibit similar behavior. The brake power of the engine when biodiesel was used, were found to lower than when diesel fuel was used. However this can be hinged on remark that uneven combustion characteristics of biodiesel fuel reduced the engine brake power (Muralidharan and Vasudevan, 2011).

Conclusion: Based on the result obtained from this research work, it can be concluded that: the fuel consumption rates of the engine when biodiesel was used are higher at each load than when diesel was used. The brake power and mechanical efficiency of the engine when biodiesel was used were found to be lower than when diesel was used at each load. The brake power of the engine when biodiesel was used, were found to lower than when diesel fuel was used. However, it is feasible to use sole biodiesel to fuel and power diesel engine.

\section{REFERENCES}

Adaileh, WM; AlQdah, KS (2012). Performance of diesel engine fuelled by a biodiesel extracted from waste cocking oil. Energy Procedia 18(2012): 1317 - 1334.

Ahmed, MW; Liaquat, AM; Harijan, K(2016). Comparative engine performance analysis using diesel fuel and biodiesel derived from waste cooking oil. 4th International Conference on Energy, Environment and Sustainable Development.1st to 3rd November 2016 Jamshoro, Sindh, Pakistan

Al-dawody, MF; Al-Farhany, KA (2018). A comparative analysis of diesel engine fuelled with diesel fuel and methyl ester of waste cooking oil. Inter. J. Appl. Engineer. Res. 13(1): 14-20.

Ashutosh, KR; Kumar, N; Chauhan, BS(2013). Performance and emission study of linseed oil as a fuel for CI engine. Inter. J. Mechanic. Mechatronics Engineer. 7(5): 787-790.

Che, WMN (2018). Why does the fuel consumption of diesel engine decrease on full load and high speed?. Retrieved on the $10^{\text {th }}$ of May, 2018 from https://www.researchgate.net/post/Why_does_th e_fuel_consumption_of the_diesel_engine_decr ease_in_full_load_and_high_speed

Dharmadhikari, HM; Kumar, PR; Rao, S(2012). Performance and emissions of C.I. engine using blends of biodiesel and diesel at different injection pressures. Inter. J. Mechanic. Mechatronics Engineer. 2(2): 1-6.

Elango, T; Senthilkumar, T (2011). Performance and emission characteristics of CI engine fuelled with 
non-edible vegetable oil and diesel blends. $J$. Engineer. Sci. Technol. 6(2): 240-250.

Fallahipanah, M; Ghazavi, MA; Hashemi, M; Shahmirzaei, H (2011). Comparison of the performances of biodiesel, diesel, and their compound in diesel air standard irreversible cycles. Inter. Conf. Environ. Agric. Engineer. 15:7-13.

Friso, D (2014). Brake thermal efficiency and BSFC of diesel engines: mathematical modeling and comparison between diesel oil and biodiesel fueling. Applied Mathematical Sciences, 8(130): $6515-6528$.

Ghosh, S; Dutta, D (2012). A comparative study of the performance \& emission characteristics of a diesel engine operated on soybean oil methyl ester, pongamiapinata methyl ester and diesel. International Refereed Journal of Engineering and Science, 1(4): 22-27.

Hao, Y;Xinghu, L; Mingfei, M; Guiyue, K;Lijun, L(2016). Performance and emissions analysis of a diesel engine directly fuelled with waste cooking oil biodiesel. International Journal of Ambient Energy, 38(4):428-434.

Harinathareddy, M; Reddy, PN; Vijayakumar RK (2013). Experimental investigation of compressed ignition engine using cotton seed oil methyl ester as alternative fuel. Inter. J. Engineer. Sci. 2(1): 610 .

Hevandro, CD; André, LJ; Paulo, RADF; Anderson, DT; Pedro, HWN; Ricardo, R(2017). Performance of diesel engine fuelled with four vegetable oils, preheated and at engine working temperature. J. Brazilian Assoc. Agric. Engineer. 37(2): 302-314.

Hurdogan, E (2016). Thermodynamic analysis of a diesel engine fueled with diesel and peanut biodiesel. American Institute of Chemical Engineers Environ Pro; 35(3): 891-897.

Jindal, S; Nandwana, BP; Rathore, NS (2010).Comparative evaluation of combustion, performance, and emissions of jatropha methyl ester and karanj methyl ester in a direct injection diesel engine. Energy Fuels, 24 (3): 1565-1572.

Kolhe, AV; Shelke, RE; Khandare, SS (2014). Performance, emission and combustion characteristics of a variable compression ratio diesel engine fueled with karanj biodiesel and its blends. Inter. J. Mech. Mechatronics Engineer. 8(4): 806-813.

Kumar, K; Sharma, MP (2016).Performance and emission characteristics of a diesel engine fuelled with biodiesel blends. Inter. J. Renewable Energy Res. 6(2): 658-661.

Madalli, VSMK (2018). Why does the fuel consumption of diesel engine decrease on full load and high speed?. Retrieved on the $10^{\text {th }}$ of May, 2018

from https://www.researchgate.net/post/Why does th e_fuel_consumption_of the_diesel_engine_decr ease_in_full_load_and_high_speed

Maharana, BL; Chnadra, H (2015). Evaluation of performance of diesel engine with biodiesel. International J. Adv. Engineer. Res. Studies. 4(2):181-183.

Mamilla, VR. (2013). Performance combustion and emission evaluation of Di compression ignition engine fuelled with diesel and biodiesel blends. Published PhD Thesis, St Peter's University, Chennai.

Mamilla, VR; Mallikarjun, MV; Rao, GLN (2013). Performance analysis of IC engines with biodiesel jatropha methyl ester (JME) blends. $J$. Petrol. Technol. Alternatives Fuel. 4(5): 90-93.

Muralidharan, K; Vasudevan, D (2011). Performance, emission and combustion characteristics of a variable compression ratio engine using methyl esters of waste cooking oil and diesel blends. Appl. Energy.88: 3959-3968.

Musa, NA; Teran, GM; Yamah, SA (2016a). Performance evaluation of a diesel engine run on biodiesel produced from coconut oil and its blends. Adv. Res. 6(4):1-6.

Musa, NA; Teran, GM; Yaman, SA (2016b).Characterisation of coconut oil and its biodiesel. J. Sci. Res. Reports. 9(6): 1-6

Naik, NS; Balakrishna, B (2019). A comparative study of performance and combustion characteristics of a CI diesel engine fuelled with B20 biodiesel blends. Inter. J. Ambient Energy. 40(1): 21-27.

Nidal, HA; Khaled, AA (2015). A comparative study of almond biodiesel-diesel blends for diesel engine in terms of performance and emissions. 
Retrieved on the $14^{\text {th }}$ of July, 2018 from https://www.hindawi.com/journals/bmri/2015/52 9808/

Puneet, V; Sharma, MP(2015). Performance and emission characteristics of biodiesel fuelled diesel engines. Inter. J. Renewable Energy Res. 5(1): 245-250.

Ramakrishnan M; Rathinam TM; Viswanathan K (2018). Comparative studies on the performance and emissions of a direct injection diesel engine fueled with neem oil and pumpkin seed oil biodiesel with and without fuel preheater. Environ Sci. Pollut. Res. Int. 25(5):4621-4631

Savariraj S; Ganapathy, T; Saravanan, CG (2013). Performance, emission and combustion characteristics of fish-oil biodiesel engine. Europ. J. Appl. Engineer. Sci. Res. 2(3):26-32.
Tutunea, D; Dumitru, I (2017). Analysis of performance and emissions of diesel engine using sunflower biodiesel. IOP Conf. Ser.: Mater. Sci. Eng. 252 012085. Retrieved on the $7^{\text {th }}$ of May, 2018 from https://iopscience.iop.org/article/10.1088/1757$\underline{899 X / 252 / 1 / 012085}$

Watson, DG; Harrison, TV; Steffen, RW (2008). Data points and duration for estimating fuel consumption of a diesel engine. Agricultural Engineering International: the CIGR E-journal. Manuscript PM 08 005. X (2008):1-9 